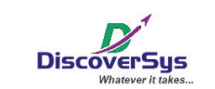

Published by DiscoverSys

\section{Relationship between Implementation of Public Health Center Management, Work Commitment and Quality of Medical Services in Public Health Centres, Karangasem, Bali}

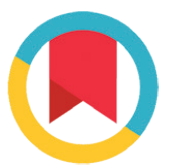

CrossMark

\section{ABSTRACT}

Background and purpose: Quality of health services in the public health centers in Karangasem remain a public health concern. Preliminary findings indicated there was a problem regarding implementation of health center management and working commitment of staff. This study aims to determine the association between quality of medical services, the implementation of health centre management and working commitment of staff.

Methods: Study was cross-sectional among 61 doctors and nurses at 12 public health centres who were selected purposively. Data were collected from February to March 2015 using questionnaires. Data analysis using logistic regression to examine the relationship between the quality of medical services with the implementation of health center management and working commitment of staff.

Results: Findings indicated that the quality of medical services, the implementation of health centre management and working commitment of staff were relatively low. The quality of medical services provided was found associated with working commitment of staff ( $A O R=11.3 ; 95 \% C: 1.75-73.06)$ and not associated with implementation of health center management ( $A O R=0.9 ; 95 \% \mathrm{Cl}: 0.18-5.24)$.

Conclusion: The quality of medical services provided was found associated with working commitment of staff and not associated with implementation of health center management.

\title{
Hubungan Penerapan Manajemen Puskesmas dan Komitmen Kerja dengan Mutu Pelayanan Pengobatan di Puskesmas Kabupaten Karangasem, Bali
}

\section{ABSTRAK}

Latar belakang dan tujuan: Mutu pelayanan di puskesmas sering menjadi keluhan masyarakat di Kabupaten Karangasem. Temuan awal menunjukkan ada masalah dalam manajemen puskesmas dan kurangnya komitmen petugas puskesmas. Penelitian ini dilakukan untuk mengetahui hubungan antara mutu pelayanan pengobatan dengan penerapan manajemen puskesmas dan komitmen kerja petugas. Metode: Survei cross sectional dilakukan pada 61 orang dokter dan perawat yang bertugas di 12 poliklinik umum dan dipilih secara purposive. Data dikumpulkan pada Bulan Februari sampai Maret 2015 dengan wawancara menggunakan kuesioner. Analisis data secara multivariat dilakukan dengan mempergunakan regresi logistik untuk mengetahui hubungan antara mutu pelayanan pengobatan dengan penerapan manajemen puskesmas dan komitmen kerja petugas. Hasil: Hasil penelitian menunjukkan bahwa mutu pelayanan pengobatan, penerapan manajemen dan komitmen kerja masih kurang. Analisis multivariat menunjukkan bahwa mutu pelayanan pengobatan berhubungan dengan komitmen kerja petugas dengan adjusted $0 \mathrm{R}=11,3$ (95\%Cl: 1,75-73,06), namun tidak berhubungan dengan penerapan manajemen puskesmas dengan adjusted $0 \mathrm{R}=0,9(95 \% \mathrm{Cl}: 0,18-5,24)$.

Simpulan: Mutu pelayanan pengobatan dijumpai berhubungan dengan komitmen kerja petugas tetapi tidak berhubungan dengan penerapan manajemen puskesmas.
2Public Health Postgraduate Program Udayana University, ${ }^{3}$ School of Public Health Udayana University,

${ }^{4}$ Bangli General Hospital

*Correspondence to: Komang Artini, Karangasem Health Office kmgartini@gmail.com
Kata kunci: manajemen puskesmas, komitmen kerja, mutu pelayanan

Kutip artikel ini: Artini, K., Suarjana, I.K., Wijaya, I.P.G. 2016. Hubungan Penerapan Manajemen Puskesmas dan Komitmen Kerja dengan Mutu Pelayanan Pengobatan di Puskesmas Kabupaten Karangasem, Bali. Public Health and Preventive Medicine Archive 4(1): 35-41. D01:10.15562/phpma. v4i1.53 


\section{PENDAHULUAN}

Rendahnya mutu pelayanan di puskesmas sering menjadi keluhan dari masyarakat. ${ }^{1}$ Ketidakpuasan masyarakat terhadap mutu pelayanan di puskesmas umumnya terkait dengan layanan pengobatan. Hasil studi di Indonesia menunjukkan mutu layanan di balai pengobatan (BP) umum puskesmas masih rendah sehingga menimbulkan ketidakpuasan. Sebagai contoh di BP Umum Puskesmas Kabupaten Tasikmalaya ditemukan tingkat kepuasan masih dalam kategori kurang. ${ }^{2}$ Penelitian lain terkait mutu pelayanan juga dilakukan di Puskesmas Mibo Banda Aceh dan menemukan bahwa jumlah rujukan atas permintaan pasien yang cukup tinggi, dengan alasan keterbatasan variasi obat yang diberikan. ${ }^{3}$ Selain tidak memenuhi harapan masyarakat dalam memberi pelayanan kesehatan yang berkualitas sesuai dengan kode etik dan standar profesi, kondisi tersebut juga tidak sesuai dengan standar Program Jaminan Kesehatan Nasional (JKN). JKN menuntut puskesmas agar mampu memberikan pelayanan pengobatan yang baik, karena puskemas merupakan gate keeper dalam penerapan pelayanan rujukan berjenjang.

Hal tersebut juga terjadi di Kabupaten Karangasem. Berdasarkan penelitian pendahuluan terhadap 10 orang pasien, 10 orang petugas puskemas dan 3 orang kepala puskesmas, diketahui bahwa terdapat beberapa keluhan dari pasien antara lain pasien sering menunggu petugas, petugas kurang ramah, ketelitian dan masih kurangnya kecepatan petugas dalam memberikan pelayanan. Di sisi lain petugas pelayanan pengobatan mengeluh bahwa ada beberapa alat kesehatan masih kurang dan beberapa obat yang tidak tersedia. Kepala puskesmas mengakui bahwa masih ada keluhan masyarakat terkait dengan mutu pengobatan di puskesmas yang disampaikan secara langsung maupun dipublikasikan melalui media massa. Hal tersebut kemungkinan menjadi penyebab angka rujukan yang cukup tinggi dan penurunan jumlah kunjungan seperti yang diamati saat ini. Pada tahun 2013, angka rujukan di puskesmas sebesar 20\% melebihi target yang ditetapkan yaitu sebesar 15\%. Penurunan kunjungan pasien yang tercatat dalam tiga tahun terakhir adalah tahun 2011 sebanyak 281.676 kunjungan (63,0\%), tahun 2012 sebanyak 243.916 kunjungan $(53,5 \%)$ dan tahun 2013 sebesar 238.018 kunjungan $(52,1 \%){ }^{4}$

Pelayanan kesehatan yang berkualitas perlu ditunjang oleh adanya manajemen puskesmas yang baik dan tersedianya tenaga yang profesional. ${ }^{5}$ Namun, beberapa penelitian sebelumnya menunjukkan hubungan pelaksanaan manajemen di puskesmas dengan capaian program menunjukkan hasil yang beragam. Ada penelitian yang menunjukkan adanya hubungan pelaksanaan manajemen di puskesmas dengan cakupan kegiatan pada program Pemberantasan Penyakit Demam Berdarah Puskesmas Kabupaten Gerobogan (Jawa Tengah). ${ }^{6}$ Penelitian lain tidak menunjukkan ada hubungan, yaitu pelaksanaan manajemen dengan keberhasilan program PMT di Puskesmas Kabupaten Tegal (Jawa Tengah). ${ }^{7}$ Observasi awal di tiga puskesmas Kabupaten Karangasem menunjukkan bahwa pelaksanaan manajemen puskesmas di puskesmas Kabupaten Karangasem belum berjalan optimal. Hal ini terlihat dalam pembuatan perencanaan tingkat puskesmas (PTP) belum dilakukan dengan baik, diantaranya karena pembuatan rencana kegiatan tidak dilaksanakan berdasarkan analisa kebutuhan, namun lebih sering melaksanakan instruksi Dinas Kesehatan Kabupaten Karangasem. Penyampaian rencana usulan kegiatan yang diajukan ke dinas kesehatan juga tidak tepat waktu, sehingga dinas kesehatan mengalami kesulitan dalam mengajukan anggaran ke Pemerintah Daerah Kabupaten Karangasem.

Tenaga profesional dan berkualitas merupakan modal utama untuk menghasilkan pelayanan kesehatan yang bermutu. Tenaga berkualitas artinya pekerja mempunyai pendidikan dan keahlian, motivasi dan komitmen pada pekerjaan dan organisasi. ${ }^{1}$ Hasil penelitian yang menghubungkan komitmen staf dengan kualitas pelayanan di Hotel Bali Hyatt Sanur (Bali) menunjukkan bahwa komitmen organisasi berpengaruh signifikan terhadap kualitas layanan; yaitu karyawan yang memiliki komitmen kuat terhadap organisasi akan meningkatkan kualitas layanan yang diberikan. ${ }^{8}$ Berdasarkan hasil wawancara awal dengan kepala puskesmas di Kabupaten Karangasem diketahui bahwa komitmen kerja pegawai di puskesmas masih kurang. Hal ini dilihat dari beberapa hal seperti terjadi kesulitan dalam membagi pekerjaan karena pegawai sering menolak tugas, tidak berada di tempat kerja pada siang hari, petugas tidak memiliki inisiatif dan inovasi dalam pengembangan program atau hanya melanjutkan kegiatan yang sudah berjalan dan menjadi rutinitas.

Karena belum pernah dilakukan penelitian sebelumnya dan untuk dapat memberikan masukan dalam upaya meningkatkan kualitas pelayanan di puskesmas Kabupaten Karangasem, maka diperlukan penelitian untuk membuktikan apakah penerapan manajemen puskesmas dan komitmen kerja petugas berhubungan dengan mutu pelayanan pengobatan di puskesmas.

\section{METODE}

Penelitian ini menggunakan rancangan survei analitik kuantitatif dengan pendekatan cross-sectional. 
Penelitian dilakukan di 12 poliklinik umum puskesmas di Kabupaten Karangasem. Populasi penelitian adalah dokter (45 orang) dan perawat (146 orang), dengan jumlah total 191 orang. Besar sampel ditentukan berdasarkan rumus besar sampel untuk proporsi dengan $\alpha=0,05$, proporsi mutu pelayanan (65\%), ${ }^{9}$ dan presisi $10 \%$; menghasilkan total sampel sebesar 61 orang (14 dokter dan 47 perawat). Sampel dipilih secara purposive yaitu petugas yang sedang bertugas di poliklinik umum puskesmas pada saat pewawancara mengunjungi puskesmas yang bersangkutan pada Bulan Februari-Maret 2015 dan telah memberikan persetujuan dengan menandatangani informed consent. Wawancara dilakukan oleh peneliti dengan menggunakan kuesioner yang dikembangkan dan dimodifikasi dari buku pedoman manajemen puskesmas dan kuesioner penelitian sebelumnya. Kuesioner penelitian telah diujicoba dan direvisi sebelum digunakan.

Variabel independen yang diteliti adalah penerapan manajemen puskesmas dan komitmen kerja petugas, sedangkan variabel dependennya yaitu mutu pelayanan pengobatan. Penerapan manajemen puskesmas terdiri dari tiga sub variabel yaitu perencanaan, pelaksanaan dan pengendalian, pengawasan dan pertanggungjawaban. Perencanaan dinilai dari ada tidaknya rencana kegiatan yang disusun penanggungjawab program pengobatan di puskesmas meliputi perencanaan target kunjungan, kebutuhan dana, tenaga, obat dan alat kesehatan, rencana usulan dan rencana pelaksanaan kegiatan. Pelaksanaan dan pengendalian dinilai dari item pelaksanaan kegiatan program pengobatan meliputi ada tidaknya loka karya mini, penyusunan tim pelaksana dan jadwal jaga. Pengawasan dan pengendalian dinilai dari item kegiatan evaluasi dan pelaporan yang dilaksanakan oleh pihak internal dan eksternal puskesmas, yang meliputi pengawasan kepala puskesmas dan dinas kesehatan, serta pembuatan laporan kinerja. Komitmen kerja petugas terdiri dari tiga subvariabel yaitu inisiatif, penghayatan visi misi dan ketaatan terhadap peraturan puskesmas. Inisiatif adalah kreatifitas dokter dan perawat dalam memberikan pelayanan pengobatan; meliputi inovasi untuk mengembangkan layanan, pengembangan kompetensi dan semangat melayani dan berorientasi pada kepuasan pasien. Penghayatan visi misi adalah pemahaman dan pelaksanaan cita-cita bersama untuk pengembangan program pengobatan di puskesmas Kabupaten Karangasem yang dinilai dari pengetahuan, sosialisasi, dan pelayanan sesuai visi misi. Ketaatan terhadap peraturan dinilai dari ketaatan pada peraturan yang telah dibuat di puskesmas terkait dengan program pengobatan dan kepentingan petugas. Itemitemnya adalah kepatuhan terhadap jam pelayanan, tata tertib pembagian tugas dan pembagian jasa pelayanan. Mutu pelayanan pengobatan terdiri dari lima sub variabel yaitu bukti fisik, kehandalan, daya tanggap, jaminan, dan empati; yang diambil dan dimodifikasi dari kuesioner yang sudah sering digunakan dalam pengukuran mutu. ${ }^{9}$

Analisis data dilakukan setelah variabel dan sub variabel dikelompokkan menjadi dua kategori. Penerapan manajemen dikelompokkan menjadi penerapan manajemen baik $(\geq 2$ sub variabel dalam kategori baik) dan kurang ( $<2$ sub variabel dalam kategori baik). Masing-masing sub variabel penerapan manajemen puskesmas dikategorikan menjadi kategori baik ("ya" $\geq 55 \%$ skor total) dan kurang ("ya" $<55 \%$ skor total). Komitmen kerja petugas dikelompokkan menjadi baik ( $\geq 2$ sub variabel komitmen baik) dankurang $(<2$ subvariabelkomitmen baik). Masing-masing sub-variabel komitmen kerja petugas dikategorikan menjadi kategori baik ("ya" $\geq 65 \%$ skor total) dan kurang ("ya" $<65 \%$ skor total). Mutu pelayanan pengobatan di kelompokkan menjadi mutu pelayanan pengobatan baik ( $\geq 4$ sub variabel mutu pelayanan baik) dan kurang ( $<4$ sub variabel mutu pelayanan baik). Masing-masing sub variabel mutu pelayanan pengobatan dikategorikan menjadi kategori baik ("ya" $\geq 65 \%$ skor total) dan kategori kurang ("ya" $<65 \%$ skor total).

Analisis univariat dilakukan untuk mengetahui distribusi frekuensi dan proporsi karakteristik responden, penerapan manajemen puskesmas dan komitmen kerja petugas, serta mutu pelayanan kesehatan. Analisis multivariat dilakukan dengan uji regresi logistik dengan metode eliminasi enter yaitu memasukkan semua variabel sekaligus ke dalam model, untuk mengetahui hubungan penerapan manajemen puskesmas dan komitmen kerja petugas dengan mutu pelayanan pengobatan.

Penelitian ini sudah dinyatakan laik etik oleh Komisi Etik Penelitian Fakultas Kedokteran Universitas Udayana/Rumah Sakit Umum Pusat Sanglah Denpasar.

\section{HASIL}

Sebagian besar responden berumur $\geq 39$ tahun $(57,4 \%)$, jenis kelamin perempuan $(52,5 \%)$, bekerja sebagai perawat $(77,1 \%)$, dan memiliki masa kerja $\geq 15$ tahun (57,4\%). Pada Tabel 1 disajikan hasil tabulasi silang antara penerapan manajeman dan komitmen dengan mutu pelayanan pengobatan. Terlihat bahwa penerapan manajemen puskesmas dijumpai masih termasuk dalam kategori kurang yaitu perencanaan (50,5\%), pelaksanaan dan pengendalian $(54,1 \%)$ dan pengawasan dan pertanggungjawaban $(54,1 \%)$. Dua sub variabel komitmen juga dijumpai dalam kategori kurang yaitu inisiatif $(54,1 \%)$ dan penghayatan visi misi 


\begin{tabular}{|c|c|c|c|c|c|}
\hline \multirow{3}{*}{\multicolumn{2}{|c|}{ Sub variabel }} & \multirow{2}{*}{\multicolumn{2}{|c|}{$\begin{array}{c}\text { Penilaian } \\
\text { Ya }\end{array}$}} & \multicolumn{2}{|c|}{ Kategori } \\
\hline & & & & \multirow{2}{*}{$\begin{array}{c}\text { Kurang } \\
\mathbf{f}(\%)\end{array}$} & \multirow{2}{*}{$\begin{array}{l}\text { Baik } \\
f(\%)\end{array}$} \\
\hline & & $\mathbf{f}$ & $(\%)$ & & \\
\hline \multicolumn{2}{|c|}{ Perencanaan } & & & $31(50,8)$ & $30(49,2)$ \\
\hline 1 & Menyusun rencana target kunjungan & 0 & 0,0 & & \\
\hline 2 & Menyusun rencana kebutuhan dana & 0 & 0,0 & & \\
\hline 3 & Menyusun rencana tenaga & 61 & 100,0 & & \\
\hline 4 & Menyusun rencana obat dan bahan habis pakai & 61 & 100,0 & & \\
\hline 5 & Menyusun rencana alat kesehatan & 61 & 100,0 & & \\
\hline 6 & Memuat dalam rencana usulan kegiatan puskesmas & 25 & 40,9 & & \\
\hline 7 & Memasukkan rencana pelaksanaan kegiatan puskesmas & 28 & 45,9 & & \\
\hline \multicolumn{2}{|c|}{ Pelaksanaan dan pengendalian } & & & $33(54,1)$ & $28(45,9)$ \\
\hline 1 & Dilakukan lokakarya mini (lokmin) lintas program & 61 & 100,0 & & \\
\hline 2 & Membahas program pengobatan dalam lokmin & 61 & 100,0 & & \\
\hline 3 & Lokmin lintas sektor membahas program pengobatan & 35 & 57,4 & & \\
\hline 4 & Dibuat jadwal petugas di poliklinik umum & 46 & 75,4 & & \\
\hline 5 & Dilakukan survei kepuasan oleh pihak internal & 12 & 19,7 & & \\
\hline 6 & Dilakukan survei kepuasan oleh pihak eksternal & 2 & 3,3 & & \\
\hline \multicolumn{2}{|c|}{ Pengawasan dan pertanggungjawaban } & & & $33(54,1)$ & $28(45,9)$ \\
\hline 1 & Pemantauan keberadaan petugas & 35 & 57,4 & & \\
\hline 2 & Pengawasan ketepatan waktu pelayanan & 37 & 60,7 & & \\
\hline 3 & Pengawasan pencatatan dan pelaporan & 34 & 55,7 & & \\
\hline 4 & Monitoring dinkes dalam penggunaan obat-obatan & 60 & 98,4 & & \\
\hline 5 & Monitoring dinkes dalam ketersediaan SOP di poliklinik umum & 6 & 9,8 & & \\
\hline \multicolumn{2}{|c|}{ Inisiatif } & & & $33(54,1)$ & $28(45,9)$ \\
\hline 1 & Adanya keinginan berinovasi & 28 & 54,1 & & \\
\hline 2 & Adanya upaya meningkatkan kompetensi & 39 & 63,9 & & \\
\hline 3 & Terjalinnya kerjasama tim di poliklinik umum & 59 & 96,7 & & \\
\hline 4 & Adanya keinginan pindah tempat tugas & 30 & 49,2 & & \\
\hline \multicolumn{2}{|c|}{ Penghayatan visi misi } & & & $41(67,2)$ & $20(32,8)$ \\
\hline 1 & Mengetahui visi misi puskesmas & 19 & 31,2 & & \\
\hline 2 & Visi misi disosialisasikan kepada seluruh staf & 21 & 34,5 & & \\
\hline 3 & Pelayanan pengobatan berdasarkan visi misi & 18 & 29,5 & & \\
\hline \multicolumn{2}{|c|}{ Ketaatan terhadap peraturan puskesmas } & & & $21(34,4)$ & $40(65,6)$ \\
\hline 1 & Selalu mengikuti aturan jam pelayanan & 51 & 83,6 & & \\
\hline 2 & Selalu mengikuti tata tertib puskesmas & 57 & 93,4 & & \\
\hline 3 & Puas terhadap aturan tata tertib & 47 & 77,1 & & \\
\hline 4 & Puas terhadap aturan pembagian tugas & 44 & 72,1 & & \\
\hline \multicolumn{2}{|c|}{ Bukti fisik } & & & $46(75,4)$ & $15(24,6)$ \\
\hline \multicolumn{2}{|c|}{ Kehandalan } & & & $129(19,7)$ & $49(80,3)$ \\
\hline \multicolumn{2}{|c|}{ Daya tanggap } & & & $40(65,6)$ & $21(34,4)$ \\
\hline \multicolumn{2}{|c|}{ Jaminan } & & & $31(50,8)$ & $30(49,2)$ \\
\hline \multicolumn{2}{|c|}{ Empati } & & & $12(19,7)$ & $49(80,3)$ \\
\hline
\end{tabular}


Tabel 2 Hubungan penerapan manajemen puskesmas dan komitmen kerja petugas dengan mutu pelayanan pengobatan

\begin{tabular}{|c|c|c|c|c|}
\hline \multirow[b]{2}{*}{ Variabel } & \multirow[b]{2}{*}{ Kategori } & \multicolumn{2}{|c|}{ Mutu pelayanan pengobatan } & \multirow[b]{2}{*}{ Nilai p } \\
\hline & & $\begin{array}{l}\text { Baik } \\
\text { f (\%) }\end{array}$ & $\begin{array}{c}\text { Kurang } \\
\mathbf{f}(\%)\end{array}$ & \\
\hline \multirow[t]{2}{*}{ Penerapan manajemen puskesmas } & Baik & $11(73,3)$ & $18(39,1)$ & 0,02 \\
\hline & Kurang & $4(26,7)$ & $28(60,9)$ & \\
\hline \multirow[t]{2}{*}{ Perencanaan } & Baik & $11(73,3)$ & $19(41,3)$ & 0,03 \\
\hline & Kurang & $4(26,7)$ & $27(58,7)$ & \\
\hline \multirow[t]{2}{*}{ Pelaksanaan pengendalian } & Baik & $9(60,0)$ & $19(41,3)$ & 0,2 \\
\hline & Kurang & $6(40,0)$ & $27(58,7)$ & \\
\hline \multirow[t]{2}{*}{ Pengawasan dan pertanggungjawaban } & Baik & $11(73,3)$ & $17(36,9)$ & 0,01 \\
\hline & Kurang & $4(26,7)$ & $29(63,1)$ & \\
\hline \multirow[t]{2}{*}{ Komitmen kerja petugas } & Baik & $13(86,7)$ & $17(36,9)$ & 0,001 \\
\hline & Kurang & $2(13,3)$ & $29(63,0)$ & \\
\hline \multirow[t]{2}{*}{ Inisiatif } & Baik & $11(73,3)$ & $17(36,9)$ & 0,01 \\
\hline & Kurang & $4(26,7)$ & $29(63,1)$ & \\
\hline \multirow[t]{2}{*}{ Penghayatan visi misi } & Baik & $8(53,3)$ & $12(26,1)$ & 0,05 \\
\hline & Kurang & $7(46,7)$ & $34(73,9)$ & \\
\hline \multirow[t]{2}{*}{ Ketaatan } & Baik & $13(86,7)$ & $27(58,7)$ & 0,05 \\
\hline & Kurang & $2(13,3)$ & $19(41,3)$ & \\
\hline
\end{tabular}

Tabel 3 Adjusted OR penerapan manajemen puskesmas dan komitmen kerja petugas terhadap mutu pelayanan pengobatan di puskesmas Kabupaten Karangasem tahun 2015

\begin{tabular}{lcccc}
\hline & & \multicolumn{2}{c}{$\mathbf{9 5 \% \mathbf { C l }}$} & \multirow{2}{*}{ Nariabel } \\
\cline { 3 - 4 } & Adjusted OR & Batas bawah & Batas atas & Nilai p \\
\hline Penerapan manajemen puskesmas & 0,9 & 0,18 & 5,24 & 0,98 \\
Komitmen kerja & 11,3 & 1,75 & 73,06 & 0,01 \\
\hline
\end{tabular}

$(67,2 \%)$. Satu sub variabel komitmen yaitu ketaatan terhadap peraturan puskesmas termasuk kategori baik dijumpai sebesar 65,6\%. Pada Tabel 1 juga terlihat bahwa mutu pelayanan pengobatan yang termasuk dalam kategori kurang adalah bukti fisik $(75,4 \%)$, daya tanggap $(65,6 \%)$ dan jaminan $(50,8 \%)$. Dua sub variabel lainnya dijumpai dalam kategori baik yaitu kehandalan $(80,3 \%)$ dan empati $(80,3 \%)$.

Pada Tabel 2 disajikan hasil tabulasi silang antara penerapan manajemen dan komitmen kerja petugas dengan mutu pelayanan. Terlihat bahwa dari 15 orang petugas yang mutu pelayanan pengobatannya baik sebanyak 11 orang $(73,3 \%)$ menerapkan manajemen puskesmas dengan baik. Sedangkan dari 46 orang petugas yang mutu pelayanan pengobatan- nya kurang sebanyak 18 orang $(39,1 \%)$ menerapkan manajemen puskesmas yang baik. Perbedaan proporsi ini yaitu $73,3 \%$ vs $39,1 \%$ secara statistik dijumpai bermakna $(\mathrm{p}=0,02)$. Demikian pula halnya dengan komitmen kerja petugas, sebanyak $86,7 \%$ yang mutu pelayanan pengobatannya baik memiliki komitmen kerja yang baik, sedangkan petugas dengan mutu pelayanan kurang hanya 36,9\% mempunyai komitmen kerja yang baik $(\mathrm{p}=0,001)$.

Pada Tabel 3 disajikan hasil analisis multivariat dengan mempergunakan regresi logistik. Terlihat bahwa variabel yang secara signifikan berhubungan dengan mutu pelayanan pengobatan hanya komitmen kerja petugas dengan adjusted $\mathrm{OR}=11,3$ (95\%CI: 1,75-73,06). Sedangkan variabel peneran manajemen puskesmas dijumpai tidak berhubungan dengan mutu pelayanan pengobatan dengan adjusted OR=0,9 (95\%CI: 0,18-5,24).

\section{DISKUSI}

Hasil penelitian ini menunjukkan bahwa komitmen kerja petugas dijumpai meningkatkan mutu pelayanan pengobatan di poliklinik umum puskemas Kabupaten Karangasem. Sedangkan 
penerapan manajemen puskesmas dijumpai tidak berhubungan dengan mutu pelayanan pengobatan. Dalam penelitian ini dijumpai bahwa komitmen kerja yang baik memberikan peluang untuk menghasilkan mutu pelayanan pengobatan baik sebesar 11,3 kali dibanding komitmen kerja yang kurang. Saat ini penelitian terkait dengan komitmen kerja petugas yang dihubungkan dengan mutu pelayanan di puskesmas masih terbatas. Namun penelitian lain terkait komitmen kerja dengan mutu pelayanan pada bidang non kesehatan telah banyak dilakukan. Sehubungan dengan hal tersebut maka hasil penelitian ini lebih banyak dibandingkan dengan penelitian pada institusi lain yang juga memberikan pelayanan (non kesehatan) kepada masyarakat. Misalnya, hasil penelitian ini sejalan dengan hasil penelitian di Inggris pada 342 karyawan bank yang menunjukkan bahwa komitmen organisasi karyawan memiliki dampak yang signifikan terhadap kualitas layanan yang diberikan. ${ }^{7}$ Penelitian lain di Kantor Bersama Samsat di Provinsi Kalimantan Timur menemukan bahwa komitmen afektif mempunyai hubungan positif yang signifikan dengan kualitas pelayanan. ${ }^{8}$ Penelitian lain di PT Freefort Papua menunjukkan bahwa seseorang dengan komitmen tinggi memiliki kemauan secara sadar untuk mencurahkan usaha demi kepentingan organisasi dan karyawan bekerja, bukan karena adanya instruksi, melainkan termotivasi dari dalam diri sendiri sehingga pelanggan merasa puas. $^{10}$ Sejalan pula dengan penelitian di Hotel Bali Hyatt Sanur Bali yang menunjukkan bahwa komitmen organisasional berpengaruh signifikan terhadap kualitas layanan yaitu jika karyawan memiliki komitmen yang kuat terhadap organisasi maka kualitas layanan yang diberikan akan semakin meningkat. ${ }^{11} \mathrm{Hal}$ ini sesuai dengan pendapat Sopiah ${ }^{9}$ bahwa karyawan yang mempunyai komitmen tinggi akan selalu berpihak dan memberikan yang terbaik kepada organisasi.

Inisiatif merupakan sub variabel dari komitmen kerja petugas yang menunjukkan hubungan dengan mutu pelayanan pengobatan pada poliklinik umum puskesmas di Kabupaten Karangasem. Hasil penelitian ini sesuai dengan hasil penelitian sebelumnya yang dilakukan pada perawat dan bidan di RSUD Kabupaten Bangli bahwa inisiatif berkaitan dengan hasil pekerjaan. Disebutkan bahwa terjadi peningkatan nilai inisiatif pada perawat dan bidan setelah pemberian intervensi penerapan Manajemen Kinerja Klinik berbasis Tri Hita Karana. Prinsip manajemen ini adalah menangani pasien dengan berlandaskan keselarasan hubungan antara manusia dengan Tuhan, manusia dengan manusia dan manusia dengan lingkungan, sehingga dapat meningkatkan kinerja perawat dan bidan di RS. ${ }^{14}$
Berkaitan dengan temuan tersebut, tampaknya hal terpenting dalam membangun komitmen kerja petugas di puskesmas adalah menumbuhkan inisiatif. Penelitian ini menunjukkan masih banyak petugas yang memiliki inisiatif kurang baik sehingga menyebabkan banyak petugas memiliki komitmen kerja kurang baik. Peneliti menduga bahwa hal ini dipengaruhi adanya keinginan untuk pindah tugas yang cukup tinggi. Temuan lain justru menunjukkan sebaliknya dimana sebanyak 6.584 karyawan di 76 rumah jompo di Mid Western State USA yang menyatakan bahwa komitmen dan kepuasan kerja dipengaruhi oleh pekerjaan dan faktor organisasi. Kurangnya komitmen dan kepuasan kerja berimplikasi pada keinginan untuk pindah. ${ }^{15}$

Dalam penelitian ini sub variabel komitmen yang cukup menonjol berhubungan dengan mutu pelayanan pengobatan adalah inisiatif petugas. Sub variabel inisiatif meliputi peningkatan motivasi untuk berinovasi, kompetensi dan kerjasama tim, serta menurunkan keinginan petugas untuk pindah. Beberapa upaya untuk peningkatan komitmen kerja petugas adalah menciptakan rasa aman dan melakukan komunikasi yang baik dengan staf, menempatkan petugas sesuai minat dan kompetensinya, meningkatkan monitoring dan evaluasi terhadap staf, serta memberikan penghargaan finansial maupun non finansial. Selain itu peningkatan komitmen diharapkan dapat meningkatkan penerapan manajemen puskesmas sehingga menghasilkan mutu pelayanan pengobatan yang lebih baik.

Keterbatasan penelitian ini adalah kemungkinan terjadi social desirable bias yaitu kecenderungan seseorang untuk menjawab pertanyaan sedemikian rupa sehingga membuat dirinya terlihat positif sesuai dengan norma standar. Selain itu, sampel penelitian tidak dipilih secara random sehingga hasil penelitian tidak bisa digeneralisir ke populasi yang lebih luas.

\section{SIMPULAN}

Mutu pelayanan pengobatan pada poliklinik umum puskesmas di Kabupaten Karangasem dijumpai masih kurang. Mutu pelayanan pengobatan dijumpai berhubungan dengan komitmen kerja petugas tetapi tidak berhubungan dengan penerapan manajemen puskesmas.

\section{UCAPAN TERIMA KASIH}

Ucapan terima kasih disampaikan kepada dokter dan perawat puskesmas di Kabupaten Karangasem yang telah bersedia untuk berpartisipasi dalam penelitian ini. 


\section{DAFTAR PUSTAKA}

1. Muninjaya, AAG. Manajemen Kesehatan Edisi 2.Jakarta: EGC; 2004.

2. Subekti D. Analisis Hubungan Persepsi Mutu Pelayanan Dengan Tingkat Kepuasan Pasien Balai Pengobatan (BP) Umum Puskesmas di Kabupaten Tasikmalaya Tahun 2009 (tesis). Semarang: Universitas Diponegoro; 2009.

3. Zuhrawardi. Analisis Pelaksanaan Rujukan Peserta PT. Askes di Puskesmas Mibo, Puskesmas Batoh, dan Puskesmas Baiturahman di Kota Banda Aceh Tahun 2007 (tesis). Medan: Universitas Sumatera Utara; 2007.

4. Dinkes Kabupaten Karangasem. Profil Kesehatan Kabupaten Karangasem. Karangasem: Dinkes Kabupaten Karangasem; 2013.

5. Kemenkes RI. Pedoman Pelaksanaan Manajemen Puskesmas. Jakarta: 2012.

6. Darwin H. Analisis Fungsi Manajemen Puskesmas yang Berhubungan dengan Pencapaian Program Penanggulangan Demam Berdarah Dengue (P2DBD) di Kota Palembang Tahun 2000 (tesis). Jakarta: Program Pascasarjana UI; 2000

7. Ningrum SF. Analisis Hubungan Fungsi Manajemen Oleh Tenaga Pelaksana Gizi dengan Tingkat Keberhasilan Program Pemberian Makanan Tambahan pada Balita Gizi Buruk di Puskesmas Kabupaten Tegal Tahun 2006, (tesis) Universitas Diponegoro; 2006.

8. Puspitawati. Kepuasan Kerja dan Komitmen Organisasional: Pengaruhnya terhadap Kualitas Layanan Hotel Bali Hyatt Sanur (tesis). Denpasar: Universitas Udayana; 2013.

9. Naya A. Hubungan Komitmen, Kerjasama dan Pengembangan Karier dengan Mutu Pelayanan pada Petugas Paramedis Unit Rawat Jalan di Puskesmas Mengwi I Kabupaten Badung (tesis). Denpasar: Universitas Udayana; 2013.
10. Malhotra N. dan Mukherjee A. The Relative Influence Of Organizational Commitment And Job Satisfaction on Service Quality Of Customer Contact Employees in Bankin Call Centres, Journal of Service Marketing. 2004.

11. Sopiah. Perilaku Organisasi. Yogyakarta: Penerbit Andi; 2008.

12. Muchtar H. Analisis Komitmen (Affective, Continuance dan Normative) Terhadap Kualitas Pelayanan Pengesahan STNK Kendaraan Bermotor (Studi Empiris pada Kantor Bersama Samsat di Propinsi Kalimantan Timur), Jurnal Manajemen dan Kewirausahaan. 2010.

13. Raymond H. Analisis Pengaruh Dukungan Organisasi Terhadap Komitmen Karyawan pada PT Freeport Indonesia; 2008.

14. Wijaya G. Penerapan Manajemen Kinerja Klinik Berbasis Tri Hita Karana pada Kepuasan Kerja, Komitmen Kerja dan Locus of Control terhadap Peningkatan Kinerja Perawat dan Bidan di Unit Rawat Inap Rumah Sakit Umum Bangli (desertasi). Denpasar: Universitas Udayana; 2012.

15. Karsh B, et al. Job and Organizational Determinants of Nursing Home Employee Commitment, Job Satisfaction and Intent to Turnover, http://www.ncbi.nlm.nih.gov/ pubmed/16253944, 2005.

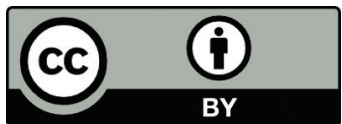

This work is licensed under a Creative Commons Attribution 